\title{
SOVIETIZATION AND NATIONALISM IN HUNGARY
}

Hungary from the Nazis to the Soviets: the establishment of the communist regime in Hungary, 1944-1948. By Peter Kenez. Cambridge: Cambridge University Press, 2006. Pp. 312. ISBN 0-52I-86766-X. £48.oo.

Agents of Moscow: the Hungarian Communist Party and the origins of socialist patriotism, 194I-I953. By Martin Mevius. Oxford: Oxford University Press, 2005. Pp. viii + 296. ISBN o-I9-92746I-4. 太69.oo.

I

Scholars of twentieth-century Hungarian history have, since the end of communism, enjoyed excellent opportunities for research. A huge amount of archival material has been declassified in the Hungarian National Archives, and the high scholarly quality of the newly established academic networks, such as the State Security Archives, the Open Society Archives, and the Institute for the ${ }_{195} 6$ Revolution, makes Hungary a research-friendly environment. Nevertheless, the post-socialist archival revolution should not be regarded as totally unprecedented. After the end of the Second World War communist authorities took over the documentary patrimony of the entire country, and declared all public papers produced by governmental bodies, religious denominations, and private citizens up to I945 open to research (previously, research was only allowed in the case of pre-I867 public documents). This enabled, if not all scholars or citizens, a new generation of party historians to unveil the atrocities and political crimes committed under the Horthy regime. Although this scholarship had ideological functions and served official propaganda, it benefited from the accessibility of primary sources. After contemporary history partly regained its status in the second half of the ig6os, more systematic and professional investigation also became possible on a widening range of topics, and while the Habsburg monarchy maintained its primacy, more sophisticated approaches to the diplomatic, military, economic, and intellectual history of the Horthy regime anticipated many of the conclusions drawn after the political changes of i989. Interestingly enough, little valuable work was done on the Holocaust in Hungary before Randolph L. Braham began publishing his seminal work, in I98I. During the late Kádár era, cautiously critical accounts on the post-I945 socio-economic trends could be published in official reviews without risk of censorship or reprisal. Two major issues and their primary sources remained untouchable: mass illegalities perpetrated by the local communist party and Soviet troops during the transition from anti-fascist coalition to one-party system (I944-8), and the $195^{6}$ uprising. 
Official historians working on primary sources released biased, unreliable accounts, while sovietologists had only second-hand materials and oral reports to work with.

In the I99os, both Hungarian and international scholarship focused on patterns of sovietization in east-central Europe, adding proofs and arguments to the longstanding debate on the extent of Stalin's planning of post-war Europe. How much could be regarded as intentional in the formation of a Soviet external empire after I945? Was this the cause of the Cold War or its undesired consequence? How should the role of a small, defeated, and occupied country like Hungary be assessed within the Soviet sphere of influence? And what role was played by the former Western allies in the dynamics of the formation of the communist regime? ${ }^{1}$

A comparative examination of the most recent literature based on recently released primary sources shows that complex historical events cannot be explained on exclusive bases. Neglect of the broader context risks an overestimation of the explanatory value of every new bit of information discovered. Thus, my investigation might be formulated in the following way: whether the books I review below have raised good questions, and what sort of answers have they provided?

\section{I}

The end of the Second World War and the subsequent Soviet military occupation marked a dramatic crossroad in Hungary's recent history. Most infrastructure (roads, bridges, private homes, and public offices) had been destroyed or damaged, and the percentage of civil and military casualties was among the highest in Europe (only in Poland, the USSR, and Yugoslavia was it higher). The capital, Budapest, lay in ruins after a siege lasting over three months. Over half of the Jewish population had been deported and killed; survivors making return to their homeland faced popular indifference and unconcealed hostility towards their claims. The economic and humanitarian catastrophe was associated with moral crisis and uncertainty about the immediate future, a circumstance remarkably described by political scientist István Bibó in his post-war essays. ${ }^{2}$

The international position of the last ally of Nazi Germany, Hungary, could have not been more unpleasant in 1945 . Unlike Romania or Bulgaria, Hungary had been unable to emancipate itself from Hitler's rule, and both Western allies

1 On the creation of the Soviet external empire, see among others F. Gori and S. Pons (eds.), The Soviet Union and Europe in the Cold war, 1943-1953 (London, 1996); Eduard Mark, Revolution by degrees: Stalin's national front strategy for Europe, 194I-I947 (Washington, DC, 200I); and the more recent Fabio Bettanin, Stalin e l'Europa: la formazione dell'impero esterno sovietico, I94I-I953 (Rome, 2007).

2 István Bibó, Válogatott tanulmányok: második kötet 1945-1949 (Budapest, I986). Some of those essays have also appeared in an English edition, Károly Nagy (ed.), Democracy, revolution, self-determination (New York, NY, I99I). 
and the USSR regarded with little sympathy every Hungarian effort to keep some strategic influence in the Danube region. The great powers shared the opinion that the conservative and far-right elites who had ruled Hungary since I9I9 were politically and morally responsible for its shameful war record. Post-war Soviet military occupation did not simply mean a serious limitation of sovereignty striking a defeated country, but also reflected the downgrade of Hungary's international status. A brief overview of pre-I989 literature (Geir Lundestad, Charles Gati), memoirs (Stephen Kertész, Pál Auer), and archival-based fresh accounts (András D. Bán, Mihály Fülöp, Csaba Békés, and László Borhi) might lead one to the conclusion that it was not the shadow of the Cold War, but a basic lack of confidence in Hungarian political actors that prevented the West from helping the non-communist forces to build a democratic country.

The engaging works by Peter Kenez and Martin Mevius focus on the outcome of the Second World War and the communist takeover, and give remarkable contribution to a better understanding of the key factors and events leading to the country's sovietization. The perspectives from which they view the i $944^{-8}$ period, however, differ. While Mevius analyses the competing strategies the Communist Party made use of in order to increase popular support (including highly controversial steps such as the exploitation of nationalist symbols and even antiSemitic sentiments), Kenez rejects the widespread belief, dating back to Hugh Seton-Watson, in the existence of a Soviet master plan for the communist takeover in Eastern Europe. His work shows how consistent efforts were made to build up a democratic (non-conservative) political system, notably in the realm of culture, especially post-war cinema.

All authors examining the period assume the legacy of the recent past and of the ambiguous relationship to historical traditions to be major interpretative issues. There is wide consensus among scholars that until 1948 sovietization made slower progress in Hungary, a defeated and occupied territory, than in any other Eastern European country. While Bulgaria, Albania, Yugoslavia, Poland, and to a certain extent Romania were almost fully sovietized in 1947, Czechoslovakia and Hungary remained at a pre-sovietized level until mid-I948, when the local communist parties finally took over the state apparatus. This aversion could also explain why Hungary became, in 1956, the scene of the largest anti-Soviet popular uprising in the Soviet bloc. According to Johanna Granville, who recently wrote a challenging book on the international context of the I956 revolution, negative feeling towards communism and the Soviet Union was a longlasting fact, due to a 'monarchical past', but also to the extent of post-war violence perpetrated by local communists. ${ }^{3}$

Trying to explain belated sovietization in Hungary, Peter Kenez points out that the strength and peaceful resistance of non-communist (sometimes openly anti-communist) forces should not be underestimated. Unlike Czechoslovakia,

${ }^{3}$ Johanna C. Granville, The first domino: international decision making during the Hungarian crisis of 1956 (College Station, TX, 2004). 
where moderate parties shared a common view for the immediate future with the communists, the non-confessional bourgeois parties which had been allowed to function in Hungary after I945 proved much more reluctant to share the power with the left-wing alliance, and their soft opposition contributed to a slowing of the process of sovietization.

Kenez pays much attention to the attempt to build a genuinely democratic political culture after I945. As he rightly points out in chapters 3 and 4 , defeated Hungary had to overcome its own 'guilty' past. 'Reactionary' (openly right-wing and conservative) parties and civil associations were not tolerated by the Soviet authorities. The former political elite did not survive the $1944^{-} 5$ changes, with the remarkable exception of the historian Gyula Szekfü, who was appointed ambassador to Moscow and loyally served the new regime (p. 202). The noncommunist agrarian parties who won the (fair) I945 elections could gather anti-communist voters, but internal and external circumstances forced them to seek 'popular' legitimacy. This meant permanent mobilization, which had no roots in Hungarian conservatism. The call for democratic participation was rather linked to the populist movement of the interwar period, whose members became politicians, such as the first post-war minister of interior, sociologist, and writer Ferenc Erdei. However, the communists' attempt ideologically to reorient the right-wing middle class and small peasantry achieved only partial success, as the widespread peasant resistance to collectivization showed some years later.

The vitality of non-communist forces found a resounding confirmation at the 'free, but not fair' elections of August 1947 when, in spite of massive illegal cheating by the communists, they were able to take an absolute majority of popular votes. One could conclude that further developments did not depend on the capacity of the Hungarian anti-communist forces to resist sovietization, but rather on the ruthless implementation of previous Soviet blueprints. Csaba Békés recently wrote that Hungary's pre-I948 peculiar pluralism was due neither to Western pressure, nor to alleged Soviet non-interest in the external periphery. On the contrary, quotes from Mátyás Rákosi's speech at the Magyar Kommunista Párt' (MKP) Central Committee meeting of I7 May, I946 make it clear that Stalin was calling for a 'new phase of the class struggle'. 4 The Soviet leadership thought that new opportunities for consolidating the USSR's position in Eastern Europe would be made possible if co-operation with the Western allies continued, giving a period of twenty or thirty years of peacetime for the region as well. Adapting Vojtech Mastny's general scheme to Hungary, Békés argues that it was internal pacification and international co-operation, and not the beginning of the Cold War, that allowed the rapid, peaceful and (at least politically) successful transition to sovietization.

${ }^{4}$ Csaba Békés, Európából Európába: Magyarország konfliktusok kereszttüzében, 1945-199o (Budapest, 2004), p. $5^{\mathrm{I}}$. 
To understand better how difficult it was for the Hungarian communists to carry out the total political takeover is it also worth investigating - as Martin Mevius does in the excellent fourth chapter of his book - the role of the collective memory of the brief communist experience of I 19 , which had shocked Hungarian society for its 'anti-national' radicalism. Mevius defines the 'Igrg legacy' (p. 69) as a basic misunderstanding, mainly due to an overly ideological approach, of the national past as a rational process, which was particularly evident in the antinationalist, but also anti-patriotic way the socialist and the bourgeois-radical movements approached the ethnic problems of Greater Hungary before the First World War. In the spring of 1919 compensation mechanisms and ideological dogmas had intertwined, for example, when the Bolshevik Republic of Councils called the working class to military defence of Hungary's borders, threatened by an 'imperialist' Czech army enjoying Entente support. This desperate intervention, which any Hungarian nationalist could have been proud of on the eve of the Trianon peace treaty, was successively downplayed to a tactical manoeuvre or even denied, because it did not fit into the internationalist self-narrative of MKP. Twenty-five years later, in $1945^{-6}$, contradictions on the national question emerged again about the imminent peace conference, which had a tremendous impact on the implementation of the new national line imposed by Moscow in October 1944. It was at this point, after Romania had left the anti-Soviet coalition and the Soviet Army penetrated into Hungary, that the party in Hungary changed its name into MKP Magyar Kommunista Párt to emphasize its national character.

Soviet unpopularity can also be explained by some contingent factors. Following Krisztián Ungváry's account of the Budapest siege and the national collapse following Admiral Horthy's abduction, Mevius and Kenez discuss the social and emotional impact of liberation/occupation of Hungarian territory by the Soviet Army and internal special forces. ${ }^{5}$ The civilian population suffered huge losses - deportations, mass executions, rapes - since the Soviet troops indifferently perceived the Hungarians as enemies deserving punishment. Negative propaganda and stereotypes of the interwar period also fuelled reciprocal antipathy, while more 'primordial' factors, such as the absence of ethnic and cultural and religious ties (Slavic ancestry, or the Orthodox faith) narrowed the possibility of human contact.

Nevertheless, it seems that the most serious obstacle to the 'nationalization' of the re-established MKP was not the Soviet military occupation, but a purely internal factor, the 'Soviet' matrix of the Hungarian communist movement as a whole. Old activists' political socialization took place in the few months of the Revolution of Councils of I9I9, and Mevius convincingly argues that social

\footnotetext{
${ }^{5}$ Krisztián Ungváry, Battle for Budapest: one hundred days in World War II, trans. L. Löb (London, 2003; Hungarian edition 1998).
} 
radicalism and the refusal to cooperate with 'bourgeois' parties were more deeply rooted in the province and at rank-and-file level than among the top leadership. Mevius also analyses how the MKP tried to build up a 'national' image and credited itself as the true heir of Hungarian national ideology. Communist leaders were aware that uncompromised 'leftism' dominating the mental map of intellectual fellow travellers had provided substantial help to the consolidation and the fortune of Admiral Horthy's authoritarian regime in the interwar period. Surprisingly enough, the new 'national coalition' line could be more easily accepted by Rákosi and Révai, who had just came back from Moscow, than by Rajk or Kállai, who had spent their entire lives in Hungary and were supposed to have deeper knowledge of Hungary's conditions (p. 86).

As mentioned, the underestimation of the potential impact of national issues had a tremendously negative impact on the political legitimacy of the Hungarian left throughout the communist period. Although in the immediate post-war period the MKP progressively replaced the old guard, who had personal experience of the I9I9 Bolshevik experiment, with people who had joined the party after I944, this generational change did not help to overcome the persistent lack of a 'national' political culture. The controversial legacy of the recent past influenced both the ideological renewal and the everyday politics of the MKP. In order to gain national legitimacy, party ideologists did not hesitate to borrow from the ideological arsenal of the interwar populist intellectual movement. Between I945 and I948 Hungarian communists portrayed themselves as advocates of the 'truest' popular traditions. Textbooks and scholarship described Hungarian history as a perpetual struggle between progressive patriots - from the anti-Habsburg Calvinist kuruc fighters of the seventeenth century to the political leaders of the I848 revolution, Lajos Kossuth and Sándor Petőfi - and reactionary, clericalminded traitors of the people's interests (the labanc). The exploitation of national symbols in the coalition years was of an evident tactical nature, but it was not simply an ideology adopted to compensate for a lack of popularity. Hungarian communists created a peculiar ideological syncretism in which pro-Soviet internationalism and patriotism could cohabitate.

But why did they feel such a great need for historical legitimacy to rule the country? The standard explanation is that they were perceived as an 'antinational' force, and the Soviet troops behaved as an occupying army among a hostile civil population. This explanation might be integrated with an issue of key importance at that time. Unlike their Czechoslovak comrades, Hungarian communists could not rely on any historical experience of legal involvement in political life, except in I9I9. The collective memory of their role in I9I9 was utterly negative among many ordinary people. However, it was even more important that, unlike most Eastern European communist parties of the immediate post-war period, the MKP could not enjoy the political benefits of the controversial but popular instrument of retribution against war criminals and collaborationists, which rapidly evolved into a collective punishment of German speaking minorities in Yugoslavia, Poland, Czechoslovakia, and to a lesser extent Romania. 
The radical solution given until I948 to long-standing minority conflicts increased support of communist parties and also allowed post-war coalition governments to carry out extensive land reforms (and later nationalization) mainly on ethnic bases. Their collective punishment culminating with the expulsion of Germans from Hungary, agreed on at the Potsdam conference in July I945, brought little popularity to those parties, like the communist and the national peasant parties, who had strongly supported their expulsion for ideological and/or social reasons. ${ }^{6}$ In short, Hungarian communists were disadvantaged in this respect, too. Their country was more homogeneous and fewer people felt hatred and prejudice towards the greatest minority, ethnic Germans, whose expulsion was not universally popular even among those far right-wing intellectuals and former civil servants who had during the I93os made claims for squeezing them out from public affairs. One might also recall that supporting the retribution towards ethnic Germans could have been interpreted by the Soviet Union as a renunciation of the defence of minority rights of Hungarians living in neighbouring countries. While in other Eastern European countries anti-German policies made a unifying factor during the brief period of coalition government, in Hungary they raised widespread political debate and moral concerns among democratic politicians and intellectuals.

\section{V}

Besides economic and humanitarian recovery, in early I946 a key question for coalition governments became Hungary's participation in the peace conference. The border issue seriously affected Hungary's bilateral relations with neighbouring countries under Soviet influence, like Romania and Czechoslovakia, where ethnic Hungarians still lived in great numbers. The MKP's interest in the defence of minority rights increased after the weak electoral performance of November 1945. In April I946 communist leaders, along with ministers and other dignitaries, paid a ten-day visit to Moscow and had talks with Stalin and Foreign Minister Molotov. Hungarian communists asked for Soviet support for Hungarian territorial claims against Romania in Northern Transylvania, and after coming home they actively took part in nationalist propaganda work. However, the communists gave up their confrontational foreign policy stance after the great powers agreed, on 7 May I946, to restore pre-war borders in east-central Europe. At this point the MKP began denouncing their peasant party allies for chauvinism and irredentism.

Interwar and post-I989 openly or latent anti-Semite discourses, intellectually rooted into the so-called 'characterological' analysis of the Hungarian national development $^{7}$, have always explained the political behaviour of the Hungarian

${ }^{6}$ On the expulsion of Swabians and its collective memory see Ágnes Tóth, Hazatértek: a németországi kitelepitésböl visszatért magyarországi németek megpróbáltatásainak emlékezete (Budapest, 2008).

7 On the characterological debate, see Balázs Trencsényi: A történelem rémülete: eszmetörténeti vázlat a két világháború közötti kelet-európai nemzetkarakterológiai vitákról, in Iván Zoltán Dénes, ed., A szabadság értelmeaz értelem szabadsága: filozófiai és eszmetörténeti tanulmányok (Budapest, 2004), pp. 299-324. 
communists in ethnic terms: they were hostile to national claims and reluctant to think in terms of national interest because of their Jewish background. After the communist takeover and until the late Kádár era the complex relationship between Jews and non-Jews in the social body and within the communist party itself became a rigid taboo. Historians, sociologists, and social anthropologists simply eluded this highly sensitive issue. Moreover, official statistics helped the political effort to make the issue disappear, since Jews were removed from national censuses as a separate ethnic group or religious denomination and amalgamated to the Hungarian majority. Thanks to extensive research in the Hungarian archives, Mevius and Kenez can elaborate a multi-factorial analysis on the re-emergence of a 'Jewish question' after the end of the war, a key issue for the most recent Hungarian scholarship, too. ${ }^{8}$ According to Kenez, 'A decisively important fact was that in Hungary, unlike anywhere else in Eastern Europe, the top leadership was entirely Jewish' (p. 292).

For most survivors of the Holocaust, the recent past had taught one single but clear lesson: the perspective of bourgeois type integration into the Hungarian nation failed. Discrimination and later persecution enjoyed genuine, if not massive, popular support among the non-Jewish population, and solidarity with dispossessed Jews was sporadic and rarely effective. As a consequence, the Jewish perception of the Soviet invasion was very different from that of the Christian population. The Soviet Army occupied Hungary, but also returned personal freedom to tens of thousands of people. Although leftist Jews had always formed a minority of Jewry as a whole, in the first months following the end of the war a statistically significant number of Jews joined the MKP (one party member out of seven in 1945, according to Kenez, p. I56). In the late I940s Jews were overrepresented among the new cadres, especially in the propaganda sector, in the cultural and economic sphere, in the press, and notably also in the political police. One might add that remarkable Jewish involvement in the early communist system was not a Hungarian peculiarity: in Poland and especially in Romania, Jewish-born activists played a distinguished role in the formation of the new state, before becoming victims of ethnic purges in the early i95os.

The new regime seemed to guarantee young Jews unprecedented opportunities for upward social mobility, and gave them self-confidence by ensuring physical protection against further harassment. As Charles Gati's most recent book demonstrates, it was precisely these young but already disillusioned former party intellectuals who gathered after I953 around Imre Nagy in the attempt to reform

${ }^{8}$ Róbert Győri Szabó, A kommunista párt és a zsidóság Magyarországon, 1945-1956 (Budapest, 1997); János Gyurgyák, A zsidókérdés Magyarországon (Budapest, 200I) and Ezzé lett magyar hazátok. A magyar nemzeteszme és nacionalizmus története (Budapest, 2007). On the post-war anti-Semitism see Éva Standeisky, Antiszemitizmusok (Budapest, 2007); and András Kovács, A másik szeme: zsidók és antiszemiták a háború utáni Magyarországon (Budapest, 2008). On Jewish victims of the early communist regime see Ágnes Szalai, 'A magyarországi kommunista diktatúra zsidó áldozatai (1949-1954)', in Randolph L. Braham, ed., Tanulmányok a Holokausztról IV (Budapest, 2006), pp. 217-68. 
Hungarian communism. ${ }^{9}$ At the same time, popular anti-Semitism and its deep social and cultural roots did not disappear after i945. Workers and trade unionists openly complained to the party that their factories were still run by Jewish capitalists. In Budapest the black market was perceived as a 'Jewish affair' (Kenez, p. 159). Moreover, especially after losing the 1945 elections, the MKP did not hesitate to use violent anti-bourgeois and anti-capitalist slogans during its mass rallies, slogans which had, in the Hungarian context, an unmistakably antiSemitic connotation. As Éva Standeisky recently pointed out, this greatly contributed to the explosion of several communist-led pogroms in 1946 , during the chaotic period of hyperinflation.

Immediately following the establishment of the communist regime and for some years thereafter, nationalism, anti-Semitism, and ethnic issues were banned from the public discourse, not only in Hungary, but all over Eastern Europe. Peter Kenez and Martin Mevius help us to re-evaluate the major role these issues and contingencies played in the emergence of totalitarian dictatorships. Their valuable books also stimulate further research on a most engaging topic for students of contemporary Eastern Europe: the various uses differing communist states such as Hungary, Poland, Romania, or Yugoslavia made of national issues in their mature phase, and how this influenced the strikingly different developments in each country as they came out of their common totalitarian framework after 1989 .

9 Charles Gati, Failed illusions: Moscow, Washington, Budapest, and the 1956 Hungarian revolt (Stanford, CA, 2006). 